\title{
Microbially induced deterioration of architectural heritages: routes and mechanisms involved
}

\author{
Tikam Chand Dakal and Swaranjit Singh Cameotra*
}

\begin{abstract}
Since ancient time, magnificence and beauty have been the goals of architecture. Artists and architects used high strength, durable and beautiful stones like marble and limestone for the construction of monuments like Taj Mahal, Milan Cathedral, Roman Catacombs and Necropolis in Rome etc. These historic monuments are exposed to open air which allows the invading army of algae, cyanobacteria, fungi etc. to easily access them. The invasion of microorganisms and their subsequent interaction with mineral matrix of the stone substrate under varied environment conditions fosters deterioration of stones by multiple mechanisms resulting in loss of strength, durability, and aesthetic appearance. The review details about the major routes and mechanisms which led to biodeterioration, discusses current remedial methodologies and suggests future directions.
\end{abstract}

Keywords: Biodeterioration, Architectural heritage, Biocorrosion, Biofilm formation, Encrustation

\section{Review}

\section{Introduction}

Biodeterioration can be defined as a geophysical and geochemical process that causes undesirable physical, chemical, mechanical and aesthetic alterations and damages to historic monuments and artworks. It is a complex process that illustrates the interaction of microorganisms with its substratum and environment [1-3]. These stone structures are highly susceptible to damage by weathering and atmospheric conditions (such as light, temperature, humidity, pollutants and acid rain) [1,4-6] because of their chemical nature and petrologic properties (texture, high porosity etc). The high porosity allows penetration of water along with corrosive ions, acids and salts inside the porosity of the stone and cause severe damage to them. Besides this, stone surface supports the growth of some characteristic group of microorganisms which includes alkaliphiles, halophiles, epiliths and endoliths [7-10] which cause deterioration in many ways (Table 1). These micro-organisms through different known mechanisms of deterioration cause harm to the stone surfaces of monuments and artworks resulting in an irreversible and irreparable loss of their physical

\footnotetext{
* Correspondence: ssc@imtech.res.in

University of Modena and Reggio Emilia, Reggio Emilia, Italy Institute of Microbial Technology, Sector 39A, Chandigarh, India
}

strength, aesthetic appearance, value and information $[1,6,10-16]$ (Table 2).

Impact of environment conditions and pollutants on rate of biodeterioration

Since the time, industrial revolution began the deterioration and weathering of heritage monuments and artworks became noticeable. Environmental conditions like relative humidity, temperature, wind, light and rainfall plays a crucial role in colonization and establishment of microbial communities on the stone surfaces of monuments and artworks $[1,4,5]$. The problem is more pronounced in tropical areas where the high temperature, high relative humidity and high annual rainfall favor the growth of diverse group of microorganisms. Microbial growth and activity is a function of the environment that surrounds them. For instance, seepage of the rain water and subsequent dampening and moistening of the vertical walls of the monuments favor the colonization of diverse groups of organisms such as cyanobacteria, algae, fungi and lichens, which foster deterioration. Similarly, oxides of nitrogen and suspended particles are affecting the lichen diversity in some cities of Italy [68]. Increasing industrial activities and pollution had also modified the composition of atmosphere and consequently favored the invasion of some aggressive species of lichens such as Dirina massiliensis forma sorediata, 
Table 1 Microorganisms and environmental factors involved in biodeterioration of architectural building and artworks

\begin{tabular}{|c|c|c|c|c|c|}
\hline S.No. & Microbial group & $\begin{array}{l}\text { Microorganisms/environmental } \\
\text { factors }\end{array}$ & $\begin{array}{l}\text { Deterioration } \\
\text { type }\end{array}$ & Deterioration mechanism & Ref. \\
\hline \multirow[t]{4}{*}{1} & Photoautotrophs & Cyanobacteria & $\begin{array}{l}\text { Aesthetic and } \\
\text { chemical } \\
\text { deterioration }\end{array}$ & $\begin{array}{l}\text { Biofilm formation; color alteration; patina } \\
\text { formation; crust formation; bioweathering as } \\
\text { a consequences of calcium uptake, } \\
\text { precipitation of calcium salt and formation } \\
\text { of secondary minerals }\end{array}$ & {$[17-23]$} \\
\hline & & Lichen & $\begin{array}{l}\text { Chemical and } \\
\text { mechanical } \\
\text { deterioration }\end{array}$ & $\begin{array}{l}\text { Extraction of nutrients from stone surface; } \\
\text { oxalate formation; carbonic acids production } \\
\text { associated bioweathering; physical intrusions } \\
\text { in small pore etc. }\end{array}$ & {$[17,24-30]$} \\
\hline & & Algae & $\begin{array}{l}\text { Aesthetic and } \\
\text { chemical } \\
\text { deterioration }\end{array}$ & $\begin{array}{l}\text { Biofilm formation; color alteration; black } \\
\text { crust formation; }\end{array}$ & {$[18,21,31,32]$} \\
\hline & & Mosses and Liverworts & $\begin{array}{l}\text { Aesthetic and } \\
\text { chemical } \\
\text { deterioration }\end{array}$ & $\begin{array}{l}\text { Discoloration; green-grey patches; extraction } \\
\text { of minerals from stone surface }\end{array}$ & {$[33,34]$} \\
\hline 2 & Chemoautotrophs & $\begin{array}{l}\text { Sulfur-oxidizing, Nitrifying } \\
\text { bacteria }\end{array}$ & $\begin{array}{l}\text { Chemical } \\
\text { deterioration }\end{array}$ & Black crust formation & {$[6,23,35-40]$} \\
\hline \multirow[t]{3}{*}{3} & Chemoheterotrophs & Heterotrophic bacteria & $\begin{array}{l}\text { Aesthetic and } \\
\text { chemical } \\
\text { deterioration }\end{array}$ & $\begin{array}{l}\text { Crust formation; patina; exfoliation; color } \\
\text { alteration }\end{array}$ & {$[18,41-43]$} \\
\hline & & Actinomycetes & $\begin{array}{l}\text { Aesthetic } \\
\text { deterioration }\end{array}$ & $\begin{array}{l}\text { Whitish grey powder; patinas; white salt } \\
\text { efflorescence; }\end{array}$ & {$[18,41-43]$} \\
\hline & & Fungi & $\begin{array}{l}\text { Aesthetic, } \\
\text { chemical, } \\
\text { physical and } \\
\text { mechanical } \\
\text { deterioration }\end{array}$ & $\begin{array}{l}\text { Fungal diagenesis; color alteration; oxalate } \\
\text { formation; bioweathering by secreted acids; } \\
\text { Chelating property of secreted acids; } \\
\text { physical intrusion or penetration of fungal } \\
\text { hyphae and destabilization of stone texture }\end{array}$ & {$[23,29,44-51]$} \\
\hline 4 & Chemoorganotrophs & Sulfur-reducing bacteria & $\begin{array}{l}\text { Chemical } \\
\text { deterioration }\end{array}$ & $\begin{array}{l}\text { Conversion of sulfate into sulfite which act } \\
\text { as a source of nutrition for sulfur-oxidizing } \\
\text { bacteria }\end{array}$ & [23] \\
\hline 5 & Higher Plants & Higher Plants & $\begin{array}{l}\text { Mechanical } \\
\text { deterioration }\end{array}$ & $\begin{array}{l}\text { Intrusion of roots inside the cracks and } \\
\text { pores; collapse and detachment of stone } \\
\text { structure }\end{array}$ & {$[18,43]$} \\
\hline 6 & Other & Environment Factors & $\begin{array}{l}\text { Aesthetic } \\
\text { deterioration }\end{array}$ & $\begin{array}{l}\text { Deposition of carbonaceous particles, ash } \\
\text { and other particulate matters; bioweathering } \\
\text { effects oxides of sulfur and nitrogen; } \\
\text { Pollution has also favored the invasion of } \\
\text { some aggressive species }\end{array}$ & {$[6,36,38,52,53]$} \\
\hline
\end{tabular}

Lecanora muralis and Xanthoria parietina whose presence became apparent in past two decades in various monuments of Italy, Spain and Portugal [52,53]. The mineral matrix of the stone serves as a suitable substratum for the growth of microorganisms. The mineral composition, nature of stone substrate and surrounding environmental conditions are the major determinants of the type and extent of microbial colonization. Nevertheless, the atmosphere contains abundant of pollutants of different origin (industrial and automobiles) which have also immense biodeterioration potential. Persistent air pollutants of urban environment like oxides of sulfur, nitrogen and other carbonaceous particles, fly ash, particulate matters upon settling on the surface of the monumental stones destroy their aesthetic and artistic beauty [4-6]. Oxides of nitrogen and sulfur combine with the rain water making it acidic and showers as acid rain on the monuments. These oxides may be oxidized into their corresponding acids by the humid air or moisture present on the damp stone surfaces of monuments further worsening their physical strength and durability. Crystallization of soluble salts like sulfates and black crust formation is also considered as one of the major causes of damage to the surfaces of monumental stones and artworks $[23,69,70]$.

\section{Monumental stones and their bioreceptivity}

During historic time, people used different stones (limestones, granites, marbles etc) for the construction of magnificent monuments and for making beautiful artworks. These historic building and artworks are our heritage which tells us about the past art, architecture and enriches us with cultural values. Stones used in making these sculptural monuments were highly consolidated and 
Table 2 Major biodeteriogens of the historic monuments and artworks

\begin{tabular}{|c|c|c|c|c|c|c|}
\hline S.No. & $\begin{array}{l}\text { Monuments and } \\
\text { artworks }\end{array}$ & Examples & City/Country & $\begin{array}{l}\text { Microbe(s) involved in } \\
\text { deterioration }\end{array}$ & $\begin{array}{l}\text { Mechanism of } \\
\text { deterioration }\end{array}$ & Ref. \\
\hline \multirow[t]{4}{*}{1} & Catacombs & Abbatija tad-Dejr & Rabat, Malta & Cyanobacteria and Microalgae & $\begin{array}{l}\text { Biofilm formation and } \\
\text { filament growth inside } \\
\text { pores and cracks resulting } \\
\text { in biophysical damage. }\end{array}$ & [12] \\
\hline & & Roman Catacomb & Italy & Actinobacteria and Fungi & Biofilm formation & [41] \\
\hline & & St. Paul's Catacombs & Rabat, Malta & $\begin{array}{l}\text { Fischerella, Leptolyngbya, } \\
\text { Actinobacteria and Coccus }\end{array}$ & $\begin{array}{l}\text { Biofilm formation as a } \\
\text { result of artificial light } \\
\text { source }\end{array}$ & [12] \\
\hline & & $\begin{array}{l}\text { Palaeo-Christian } \\
\text { Catacombs }\end{array}$ & Rabat, Malta & Cyanobacteria & Biofilm formation & [12] \\
\hline \multirow[t]{6}{*}{2} & Cathedral & Cathedral of Camerino & Macerata, Italy & $\begin{array}{l}\text { Micrococcus sp., Alcaligenes sp. } \\
\text { and Flavobacterium }\end{array}$ & $\begin{array}{l}\text { Carbonate dissolution } \\
\text { and color alteration }\end{array}$ & [54] \\
\hline & & $\begin{array}{l}\text { Cathedral of Salamanca } \\
\text { and Toledo }\end{array}$ & $\begin{array}{l}\text { Salamanca and } \\
\text { Toledo in Spain }\end{array}$ & $\begin{array}{l}\text { Chlorophyta, Cyanobacteria and } \\
\text { Fungi }\end{array}$ & Biofilm formation & [8] \\
\hline & & Cathedral of Salamanca & Salamanca, Spain & $\begin{array}{l}\text { Penicillium, Fusarium } \\
\text { Cladosporium, Phoma, and } \\
\text { Trichoderma }\end{array}$ & $\begin{array}{l}\text { Acid secretion and } \\
\text { bioweathering }\end{array}$ & {$[55]$} \\
\hline & & Cathedral of Toledo & Toledo, Spain & Stichococcus bacillaris & $\begin{array}{l}\text { Biofilms and patina of } \\
\text { different colors }\end{array}$ & [4] \\
\hline & & Lund Cathedral & Lund, Sweden & $\begin{array}{l}\text { Microcoleus vaginatus and } \\
\text { Klebsormidium flaccidum }\end{array}$ & Biofilm formation & {$[2,3]$} \\
\hline & & Milan Cathedral & Milan, Italy & Cladosporium sp. & $\begin{array}{l}\text { Damage to monument } \\
\text { and previously applied } \\
\text { protective acrylic resin }\end{array}$ & {$[56]$} \\
\hline 3 & Caves & $\begin{array}{l}\text { The Painted Cave of } \\
\text { Lascaux }\end{array}$ & France & Fusarium solani & $\begin{array}{l}\text { Human activity resulted } \\
\text { in alteration in cave } \\
\text { environment and } \\
\text { introduction of fungi }\end{array}$ & [57] \\
\hline \multirow[t]{3}{*}{4} & Chapel & $\begin{array}{l}\text { Chapel of Castle } \\
\text { Herberstein }\end{array}$ & Styria, Austria & $\begin{array}{l}\text { Acremonium, Engyodontium, } \\
\text { Cladosporium, Blastobotrys, } \\
\text { Verticillium, Mortierella, Aspergillus } \\
\text { and Penicillium }\end{array}$ & $\begin{array}{l}\text { Accumulation of moisture } \\
\text { and growth of fungi }\end{array}$ & [58] \\
\hline & & Chapel of Sistine, Italy & Sistine, Italy & Bracteacoccus minor & $\begin{array}{l}\text { Biofilm and green patina } \\
\text { formation }\end{array}$ & [59] \\
\hline & & Chapel of St. Virgil & Vienna, Austria & Halococcus and Halobacterium. & Salt efflorescences & [9] \\
\hline \multirow[t]{6}{*}{5} & Church & $\begin{array}{l}\text { Carrascosa del Campo } \\
\text { Church }\end{array}$ & Cuenca, Spain & Algae, Heterotrophic Bacteria and & $\begin{array}{l}\text { Organic acid secretion, } \\
\text { and }\end{array}$ & [60]; \\
\hline & & & & $\begin{array}{l}\text { Fungi (Penicillium and Fusarium) } \\
\text { and Mosses }\end{array}$ & $\begin{array}{l}\text { decomposition and } \\
\text { humification of stones }\end{array}$ & [61] \\
\hline & & Vilar de Frades church & Barcelos, Portugal & Rubrobacter & $\begin{array}{l}\text { Biofilm formation, hyphae } \\
\text { penetration in the } \\
\text { painted layers resulting } \\
\text { into pitting, detachment, } \\
\text { cracking and loss of the } \\
\text { paint }\end{array}$ & $([62,63]$ \\
\hline & & St Maria church & $\begin{array}{l}\text { Alcala de Henares, } \\
\text { Spain }\end{array}$ & $\begin{array}{l}\text { Bacillus, Micrococcus and } \\
\text { Thiobacillus, yeast and microalgae } \\
\text { of the Apatococcus }\end{array}$ & Crust formation & [11] \\
\hline & & Magistral church & $\begin{array}{l}\text { Alcala de Henares, } \\
\text { Spain }\end{array}$ & Algae and bacteria & Biofilm formation & [11] \\
\hline & & $\begin{array}{l}\text { Parish Church of St. } \\
\text { Georgen }\end{array}$ & Styria, Austria & $\begin{array}{l}\text { Acremonium, Engyodontium, } \\
\text { Cladosporium, Blastobotrys, } \\
\text { Verticillium Mortierella, Aspergillus } \\
\text { and Penicillium }\end{array}$ & $\begin{array}{l}\text { Prolonged dampness, salt } \\
\text { and fungal growth }\end{array}$ & [58] \\
\hline \multirow[t]{2}{*}{6} & Fountains & Bibatauín Fountain & Granada, Spain & Microalgae & Biofilm formation & [17] \\
\hline & & & Granada, Spain & & Green patina and Biofilm & [31] \\
\hline
\end{tabular}


Table 2 Major biodeteriogens of the historic monuments and artworks (Continued)

\begin{tabular}{|c|c|c|c|c|c|c|}
\hline & & $\begin{array}{l}\text { Fountain of Patio de la } \\
\text { Lindaraja }\end{array}$ & & $\begin{array}{l}\text { Cyanobacteria, Chlorophyta, } \\
\text { Bacillariophyta, Fungi and } \\
\text { Diatoms (Navicula spp) }\end{array}$ & & \\
\hline & & $\begin{array}{l}\text { Fountain of Patio de la } \\
\text { Sultana }\end{array}$ & Granada, Spain & $\begin{array}{l}\text { Cyanobacteria, Chlorophyta, } \\
\text { Bacillariophyta, Fungi and } \\
\text { Diatoms (Navicula spp) }\end{array}$ & $\begin{array}{l}\text { Various colored patina } \\
\text { and Biofilm }\end{array}$ & {$[17]$} \\
\hline & & $\begin{array}{l}\text { Fountains of the } \\
\text { Alhambra }\end{array}$ & Granada, Spain & Algae & $\begin{array}{l}\text { Excessive mineralization } \\
\text { leading to change in } \\
\text { texture and composition }\end{array}$ & {$[64]$} \\
\hline & & $\begin{array}{l}\text { The Haji Mehmet } \\
\text { Fountain at Rustempasa } \\
\text { Bazaar, Erzurum, Turkey }\end{array}$ & Erzurum, Turkey & Bacteria and fungi & $\begin{array}{l}\text { Interaction of } \\
\text { microorganism with air } \\
\text { pollutants like } \mathrm{SO}_{2}, \mathrm{NO}_{2} \\
\text { etc. and biofilm formation } \\
\text { on stone surface }\end{array}$ & {$[5]$} \\
\hline & & $\begin{array}{l}\text { Lions Fountain at the } \\
\text { Alhambra Palace }\end{array}$ & Granada, Spain & $\begin{array}{l}\text { Protebacteria, Chlamydiae and } \\
\text { Verrucomicrobia }\end{array}$ & $\begin{array}{l}\text { Biofouling and } \\
\text { Biocorrosion }\end{array}$ & {$[16]$} \\
\hline & & Robba's fountain statues & Ljubljana, Slovenia & $\begin{array}{l}\text { Endolithic green algae and } \\
\text { cyanobacteria }\end{array}$ & Black crust formation & [15] \\
\hline & & Tacca's Fountains & Florence, Italy & $\begin{array}{l}\text { Cyanobacteria, Chlorophyta, } \\
\text { Bacillariophyta, Fungi and } \\
\text { Diatoms (Navicula spp) }\end{array}$ & Green and brown biofilm & {$[17]$} \\
\hline 7 & Monastery & $\begin{array}{l}\text { Santa Clara-a-Velha } \\
\text { Monastery }\end{array}$ & Coimbra, Portugal & Chlorella & Biofilm formation & {$[65]$} \\
\hline 8 & Mosque & $\begin{array}{l}\text { The Lalapasa Mosque, } \\
\text { The Erzurum Castle } \\
\text { Mosque, The Double } \\
\text { Minarets- Madrasah, The } \\
\text { Great Mosque }\end{array}$ & Erzurum, Turkey & Bacteria and fungi & $\begin{array}{l}\text { Interaction of } \\
\text { microorganism with air } \\
\text { pollutants like } \mathrm{SO}_{2}, \mathrm{NO}_{2} \\
\text { etc. and biofilm formation } \\
\text { ob stone surface }\end{array}$ & {$[5]$} \\
\hline 9 & Palace & Ajuda National Palace & Lisbon, Portugal & Chroococcidiopsis & Biofilm formation & {$[65]$} \\
\hline 10 & Pyramids & Caestius Pyramid & Rome, Italy & $\begin{array}{l}\text { Cyanobacteria: Myxosarcina } \\
\text { concinna, Calothrys marchica var. } \\
\text { crassa, Phormidium foveolarum, } \\
\text { Synechococcus sp.; Green Algae: } \\
\text { Chlorocuccum sp.; Fungi: } \\
\text { Cladosporium cladosporioides and } \\
\text { Alternaria alternata and Lichens }\end{array}$ & Pitting & [14] \\
\hline \multirow[t]{2}{*}{11} & Statues & Baboli Garden Statues & Florence, Italy & $\begin{array}{l}\text { Chroococcidiopsis, Leptolyngbya, } \\
\text { Pleurocapsa, Coccomyxa and } \\
\text { Apatococcus }\end{array}$ & $\begin{array}{l}\text { Polysaccharides secretion } \\
\text { and biofilm formation }\end{array}$ & [32] \\
\hline & & $\begin{array}{l}\text { Terracotta statue from the } \\
\text { Pardon Gate }\end{array}$ & $\begin{array}{l}\text { Cathedral of } \\
\text { Seville, Seville, } \\
\text { Spain }\end{array}$ & $\begin{array}{l}\text { Phormidium sp. and } \\
\text { Klebsormidium flaccidum }\end{array}$ & $\begin{array}{l}\text { Green and black sulfated- } \\
\text { crust and Biofilm } \\
\text { formation }\end{array}$ & {$[17]$} \\
\hline \multirow[t]{2}{*}{13} & Tombs & $\begin{array}{l}\text { Etruscan Mercareccia } \\
\text { Tomb }\end{array}$ & Italy & $\begin{array}{l}\text { Mixed population of bacteria and } \\
\text { fungi }\end{array}$ & $\begin{array}{l}\text { Stone carbonate } \\
\text { solubilization }\end{array}$ & [13] \\
\hline & & $\begin{array}{l}\text { Servilia and Postumio } \\
\text { Tombs in the Roman } \\
\text { Necropolis of Carmona, } \\
\text { Spain }\end{array}$ & Seville, Spain & Rubrobacter & $\begin{array}{l}\text { Hyphae penetration in } \\
\text { the painted layers } \\
\text { resulting into pitting, } \\
\text { detachment, cracking and } \\
\text { loss of the paint }\end{array}$ & {$[63]$} \\
\hline \multirow[t]{2}{*}{14} & Towers & Orologio Tower & Martano, Italy & Chlorella & Biofilm formation & [65] \\
\hline & & Pisa Tower, Italy & Pisa, Italy & Sporotrichum & Oxalate formation & {$[66]$} \\
\hline 15 & Walls & Lungotevere walls & Rome, Italy & Chroococcus lithophiles & Biodeterioration & {$[67]$} \\
\hline
\end{tabular}

durable and were obtained from naturally occurring sedimentary rocks which are composed of one or more minerals. These monuments and artworks exposed to polluted air and corrosive acid rain water and are now at risk of degradation and deterioration. Varieties of microbes are getting an open access and are now enjoying their royal stay in historic monuments, viewing intricately designed painting and artwork for which visitors need to pay. Microbial presence on monumental stones and artworks does not imply that the biodeterioration is associated with 
their growth. Microbial ability to colonize stone surface depends up on numerous factors like mineral composition, nutrient availability, $\mathrm{pH}$, salinity, surface texture, moisture content, porosity, permeability, climatic and micro-environmental conditions [23]. The mineralogical nature of stone together with its surface properties and environmental conditions synergistically controls the bioreceptivity of a stone (an ability of stone to be colonized by microorganisms) while the intensity of colonization is influenced by the surrounding environment conditions (including pollutants concentration and micro-climatic conditions) and by anthropogenic eutrophication of the atmosphere [71,72].

\section{Major routes to biodeterioration}

Microbes play a geoactive role in the biosphere. They can initiate, support and accelerates some geochemical and geophysical reactions which lead to biodeterioration of historic monuments [1]. The biodeterioration of historic monuments and stone works occurs as a consequence of biofilm production, secretion and deposition of organic and inorganic compounds (salt encrustation and efflorescence), physical intrusion/penetration of microbes and redox processes on cations from the mineral lattice $([23,73])$. The growth and activity of the microorganisms on monuments or stone surface results in five major alterations: bioweathering (stone dissolution), staining or color alteration, surface alterations (pitting, etching, stratification etc), biocorrosion and transformation of crystal into small size one [25].

\section{Bioweathering or stone dissolution}

Weathering is a process induced by microbial communities secreting corrosive organic and inorganic acids, metal binding ligands, resulting in progressive weathering or dissolution of superficial mineral surface of rock. Microbial-mineral interaction serves as a good ground for studying the role of microbes in the process of geochemical transformation of monumental stones and artworks. This interaction represents different methods which microbes utilize for the extraction of nutrients from the mineral surface $[23,27,69,74,75]$. The dissolution of stone provides essential trace-metals, phosphate, sulfate and metabolites to the inhabiting microbial communities which are crucial for the growth and development of inhabiting microbial consortia [76]. Fungi perform stone dissolution in two ways: by forming secondary minerals and metabolism independent binding of metals on their cell wall or other external surfaces [51,77]. The release of highly corrosive inorganic acids, organic acids and chelating agents by fungi and lichens on stone surface of monuments are among those methods which are inadvertently involved in the promotion of bioweathering process [23]. Biofilm formation though conspicuous on monumental stones and artworks but very little is documented in literature regarding their role in extraction of minerals from the stone substrates $[23,30,69]$.

\section{Biocorrosion: release of corrosive inorganic and organic acids}

Biogenic secretion or release of inorganic and organic acids by a great number of microorganisms is considered as the probable cause of biocorrosion of monumental stone surfaces. The destruction processes induced by the released inorganic and organic acids are respectively known as acidolysis and complexolysis [70]. The process of acidolysis is associated with the chemolithotrophic bacteria like nitric and sulfuric acid producing bacteria. Apart from this, the release of carbon dioxide produced during cellular respiration by lichens and mosses is also a potent corrosive agent $[24,78]$. The formation of organic acids like oxalic acids, citric acids etc by certain chemoorganotrophs and lichens have strong corrosive property.

\section{Stone encrustation: deposition of corrosive organic and inorganic compounds}

Increasing industrialization and combustion of the fossil fuel has increased the concentration of $\mathrm{SO}_{2}$ and $\mathrm{NO}_{2}$ in the atmosphere. Both $\mathrm{NO}_{2}$ and $\mathrm{SO}_{2}$ have bioweathering effect [36,38]. $\mathrm{SO}_{2}$ together with other dark particles (particulate matters) settles down and get deposited on the stone surfaces rendering darkened and yellowish color to them $[6,36]$. There is a special class of bacteria, called sulfur-oxidizing bacteria and nitrifying bacteria (chemoautotrophs) which can colonize marble surface and oxidize the nitrogen compounds including atmospheric ammonia (Nitrosomonas sp. and Nitrobacter sp.) and sulfur compounds (Thiobacillus sp.) into nitric and sulfuric acid respectively [38]. These acids are highly corrosive and accelerate the dissolution of the stone surface (biocorrosion) and changes. This acids react with the stone carbonates and results in the formation of nitrate and sulfate salts. The sulfation is stone carbonates is known to be prompted by the presence of humidity and fossil fuel derived particulate matters [37,40]. Upon coming in contact with rain water these sulfates get dissolved forming hydrated salts like gypsum [35]. The formation of gypsum is often accompanied by the entrapment of carbonaceous particles (fly ash), diesel particulate matters and dust, leading to the formation of black and brown sulfated crust over the stone [37,39]. The affects of encrustation of marble stones with sulfates is not limited to the aesthetic problems, these sulfates can precipitates inside the pores of the stones and upon recrystallization exerts considerable stress inside the pore walls resulting in structural damage to the marble stones. The chemical composition of these sulfated crusts varies and is dependent on the age of the crusts 
and particular airborne pollutants in individual areas [79]. Quite often sulfur-oxidizing bacteria are also benefited by the presence of sulfur-reducing bacteria at the base of the stone. These bacteria reduce the sulfates to sulfides, which is an excellent source of energy for the sulfur-oxidizing bacteria. The presence of extremely and moderate halophiles on the monumental stone and stone works of art is also reported. Halophiles are abundantly found on the surface of the stones and art works which are laden with the deposits of hygroscopic salts. These depositions are formed as a result of drying of salt containing water on the exposed surfaces of the stone by a process commonly known as efflorescences.

\section{Secondary mineral formation: calcium oxalate or patina formation}

Calcium oxalate formation on sculptural monuments and artworks is prominent feature of several lichens and fungal species which stains the stone surfaces with various colored patina [29]. Calcium oxalates (whewellite$\mathrm{CaC}_{2} \mathrm{O}_{4} \cdot \mathrm{H}_{2} \mathrm{O}$ and weddellite- $\mathrm{CaC}_{2} \mathrm{O}_{4} \cdot 2 \mathrm{H}_{2} \mathrm{O}$ ) widely occur in nature mainly as patina on the stones of historic monuments and artifacts. Calcium oxalates are formed as a result of precipitation of calcium carbonate by oxalic acid which is produced as a metabolic byproduct by lichens and fungi. Raman spectra analysis showed the presence of calcium oxalate monohydrate (by Lecanora sulfurea and Aspicilia calcarea) and dihydrate (Dirina massiliensis f. sorediata, D. massiliensis f. massiliensis and Tephromela atra) in the biomineral product of lichen bioweathering [80]. Earlier the precipitation of calcium in the form of oxalate was assumed to be less common in other organism like algae and fungi. During recent year several experimental demonstration were presented regarding their biogenesis [54]. The evidence of fungal biogenesis of calcium oxalate formation was also reported in literature [54]. Additionally, the origin of patina is partially attributed to past stonemasonry treatments and to atmospheric pollution [29].

\section{Biofilm formation}

Algae, microalgae and cyanobacteria are considered as the pioneering inhabitants of a stone surface hence their presence can be easily identifiable on the stones surface $[2,3,48]$. Cyanobacteria are often present in association with red algae, green algae and lichens [48]. These are the one on the major threats to the monumental and ornamental stone works of art. Due to their phototrophic nature, they easily grow on the stone forming colored patinas and incrustations [22]. Their association with substrate in the presence of water makes their growth predominates over other organisms and accelerates the formation of biofilms which facilitates attachment and serves as a mechanism for resisting adverse abiotic conditions $[17,81]$. Biofilm act as precursor for the physical damage to the stone leading to its biodeterioration $[21,48]$ and discoloration [20]. It is believed that under certain conditions almost all substrate both natural and man-made can be colonized by microorganisms enclosed within a three dimensional extracellular polysaccharides matrices called biofilm [23,73]. Biofilm composition and distribution mainly depend up on the resulting spatial and temporal variation in a number of abiotic and physicochemical factors, including micro-environment. Biofilm production on outdoor monuments that are continuously exposed to light tends to contain pleothora of phototrophic microorganisms [21]. Biofilm formation by cyanobacteria represents a mechanism to resist changes in environment like extremes of temperature, drought and prolonged exposure to light $[82,83]$. Other survival strategies which include use of water stored within substrate [84], formation of compounds conferring resistance to drought [85] and synthesis of protective UV shield $[84,86]$ are also known. Cyanobacteria have capability of extraction and mobilization of ions like calcium and potassium present on artworks for their own nutrition [81]. The biofilm is composed of cells and extracellular polymeric substance that facilitates the attachment of the biofilm on the solid substratum. Further, the biofilms enhanced $\mathrm{N}$ and $\mathrm{P}$ availabilities when inoculated in the soil [87]. The biofilm formation makes the stone lose its property of cohesion. Some genera of the microalgae such as Cosmarium, Phormidium and Symploca are the major destructors of ornamental stones collected from the fountain of Bibatauin at Granada in Spain [31]. The constant presence of water also favors the growth of some endolithic green algae and cyanobacteria which forms black crust on the Robba's fountain statues, Ljubljana (Slovenia). The stratification of biofilm is controlled by a number of factors, including the quality of light. Low light conditions tend to reduce the stratification and affect species diversity and permit only certain species to survive [88]. Biofilms can be both detrimental and beneficial, depending on the substratum and microorganisms involved. While biofilms and the inhabiting organisms accelerate the deterioration process [89], some communities have a more protective role [90]. In later case, the removal of biofilm layer may fasten the deterioration of stones by making them susceptible to atmospheric pollutants and to the attacks of salts [91,92].

\section{Redox processes on cations from the mineral lattice}

Some protein compounds called "Siderophores" are involved in the process of cation transfer from mineral matrix of the stone to microbial cells. Besides this, active ion uptake followed by accumulation of cation on microbial cell wall is another mechanism for this process. The leached cations are immobilized by the degradation of metal organic transport complexes and metal organic 
chelates. Subsequently the redox process is favored upon liberation of oxygen by cohabitant photosynthetic cyanobacterial and algae [23]. Several chemoorganotrophic bacteria and fungi (Acidithiobacillus ferrooxidans, Bacillus spp., Leptospirillum spp., Aureobasidium spp.) are facilitate the removal of cations, in particular, iron and manganese cations from the mineral lattice by oxidation and consequently contributing to deterioration of stone [23].

\section{Physical penetration of microbes}

Physical intrusion and penetration of bacterial and fungal hyphae inside the gaps, pores, cracks and boundaries of the stones has also posed a big threat to biophysical and biomechanical damage to monuments and artworks $[25,27,48,74]$. The physical intrusion by hyphae along the crystal plane destabilizes the stone texture and increases the porosity which causes biomechanical deterioration of stones and artworks [25,27,48,74]. Besides bacteria and fungi, some photosynthetic microorganisms such as mosses are known to possess rhizoids which physically intrude inside the stone but biomechanical damage caused as a result of their rhizoids intrusion is less documented in literature [48].

\section{Microorganisms involved in biodeterioration Bacteria}

Bacteria involved in deterioration of monuments and artworks mainly belong to three nutritional groups: Photoautotrophs, Chemolithoautotrophs and Chemoorganotrophs. Among phototrophs and chemolithoautotrophs are mainly cyanobacteria, sulfur-oxidizing and nitrifying bacteria were reported from the heritage sites. Due to their simpler nutritional (like inorganic minerals, atmospheric ammonia etc.) and ecological needs (like presence of light, $\mathrm{CO}_{2}$ and water) these bacteria easily develop on outdoor monuments. Among these organisms, cyanobacteria have the ability to survive under the conditions of repeated drying and rehydration occurring on exposed monument's surfaces [48] and to protect themselves by the harmful UV radiation by producing protective pigments [48]. However, their presence was also conspicuous in interior works of art $[20,93,94]$ (hypogean environments of Roman Catacombs) which were subjected to inappropriate natural or artificial illumination during visitor's hours $[81,95]$. The colonization of these photosynthetic microorganisms on external surface of monuments is related to biofilm formation, corrosive inorganic and organic acid secretion resulting in

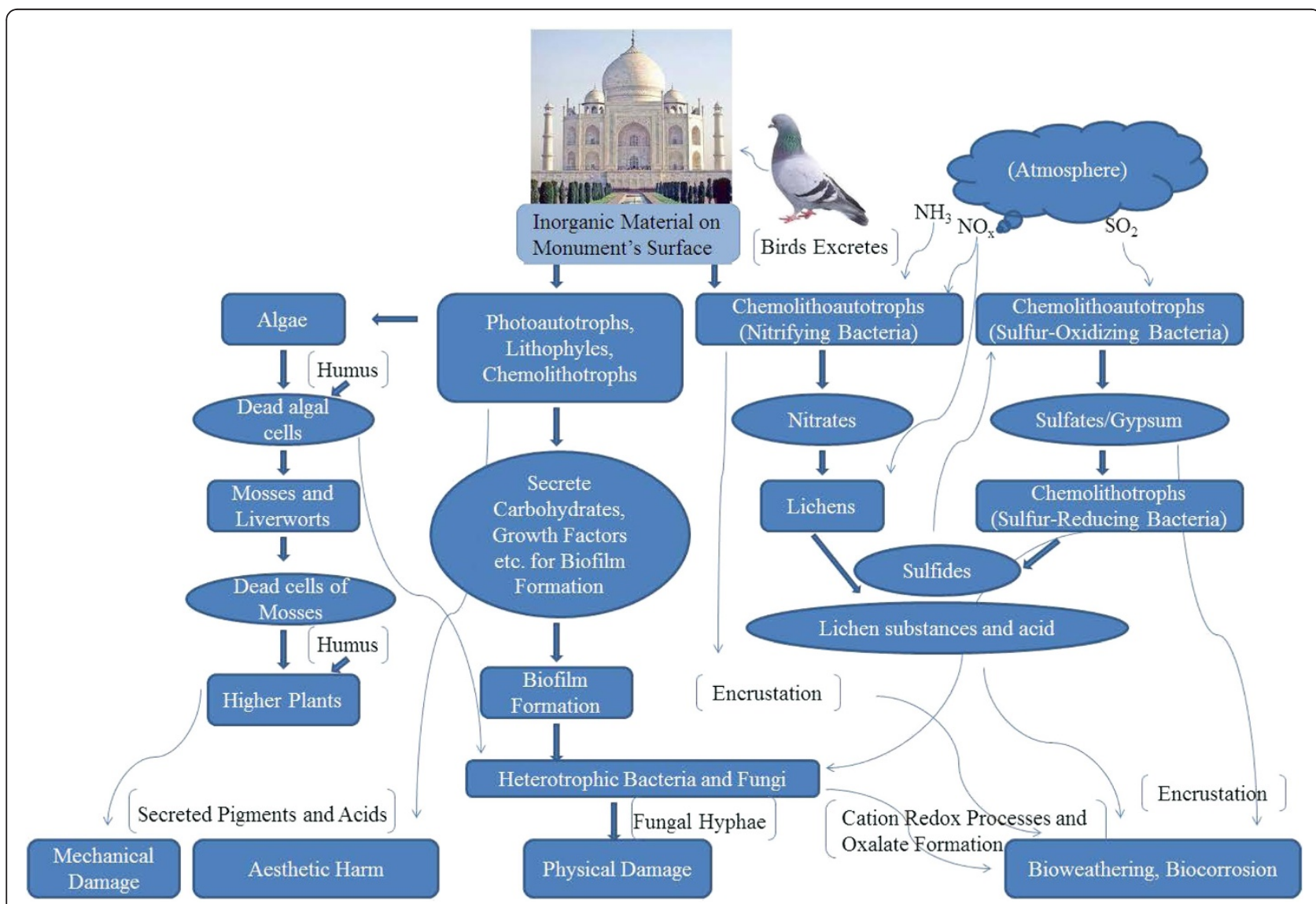

Figure $1 \mathrm{~A}$ Brief demonstration of the relationship between ecological succession and biodeterioration of monuments. 
mechanical deterioration (due to alternate shrinking and swelling cycles of biofilm) undesirable unaesthetic staining of the monuments (by secreted acids, pigments and metabolic bioproducts), enlargment of pore (due to hyphal penetration), alteration in pore size, distribution and water permeability of the minerals (by deposition of surfactants) and weathering (as a consequences of uptake of calcium, precipitation of calcium salt and secondary mineral formation) $[18,19]$. Chemoorganotrophs and chemoheterotrophs bacteria found associated with deterioration process are mainly sulfur-reducing bacteria and actinomycetes respectively. Population of these heterotrophic bacteria and actinomycetes prevail in hypogean environment characterized by stable microclimatic conditions (high relative humidity $<90 \%$, constant temperature throughout year and low photon influx) [42,96]. These bacteria are mainly responsible for the irreversible damage to the indoor artworks (wall painting, frescos, stuccoes etc) and are less involved in the deterioration of outdoor monuments. Some species belonging to order Actinomycetales like Geodermatophilaceae strains [97] and also some Micromonospora strains [98] were also isolated from monumental stones. Actinomycetes species mainly, Streptomyces ( $S$. julianum) may form intimate association with cyanobacterial partner as found in the hypogean environment of Roman Catacombs. Actinomycetes preferred to grow where there exist the growth of algae and chemosynthetic nitrogen fixer bacteria. Invasion and damage to the Caves of Lascaux by fungi Fusarium and associated bacterium Pseudomonas Fluorescens was mainly ascribed to the perturbations induced by illumination and visitor's breath $[57,99]$.

Two archaebacteria were detected and isolated from two ancient wall painting namely Catherine Chapel of the Castle Herberstein (Styria) from Austria and Roman Necropolis of Carmona from Spain. These archaeal communities were subjected to 16s rRNA sequencing and denaturing gradient gel electrophoresis and are characterized and found related to Halococcus (halophilic) and Halobacterium (alkaliphilic) [9].

\section{Fungi}

Fungi are ubiquitously present microorganisms representing the group of chemoheterotrophs characterized by the presence of unicellular or multicellular hyphae [58]. Fungi are metabolically more versatile than other biodeteriogens in the microbial kingdom. This versatility allows them to colonize on wide variety of substrates including wood, stones, and metals and enhances their biodeterioration potential. Their ability to grow on variety of substrate, endure extremes of environmental conditions, establishing mutualistic association with cyanobacteria and algae as lichens [51] and adopting various structural, morphological and metabolic strategies further enhances their versatility and adaptability $[46,100]$. The biodeterioration of inorganic substrate (like carbonate) by fungi entirely follow a different mechanism. Being heterotrophic, fungi are unable to consume the inorganic carbonate substrate to supports its growth, but can grow on the waste product or dead cells of previous communities and deposits of organic nitrogenous matters of birds excretes, decayed leaves and aerosols [51] present on rock surface, fissures, cracks, subaerial and subsoil environment. Their capability to grow as oligotrophs and scavenge nutrient material from atmospheric and rain water permits their growth on inhospitable environments of rocks [100]. The presence of fungi on the stone surface of the heritage monuments and stoneworks is often associated with the process of biodeterioration. Fungi are known to harm the monumental stones and artworks in numerous ways. Their growth on stone surface can alter it severely by the excreting inorganic and organic acids as a result of their own metabolism. These metabolically generated organic acids (like oxalic acid and citric acid) have chelating properties by which it weaken the metaloxygen bond, increases the solubility of some metals and forms complexes with the mineral cations present on the surface matrix [45,49,60,61]. Intrusion of fungal hyphae along the crystal plane by some fungi is known to destabilize the stone texture resulting in its mechanical deterioration ([100]; Gadd 2005). Another mean of mechanical damage results from the alternate contraction and expansion of the thallus under fluctuating environmental humidity conditions. Some endolithic fungi by biochemical mean cause "pitting", of the stone surface that appears to have many small holes. This alteration has been found on historic monuments such as the gate of the Cathedral of Huesca in Spain. Species of fungi of different genera such as Cladosporium herbarum, Aspergillus niger, Stachybotrys sp. and Alternaria have been found on these supports. Scanning electron microscopy also revealed the presence of 'etch marks' beneath the microorganism which is a form of biochemical weathering [24,101]. Fungi can transform and weather the mineral surface of the stone by precipitating calcium carbonate into calcium oxalate by the actions of secreted oxalic acid using the process of secondary mineral formation (or neogenesis) [44,47]. Formation of oxalate film on carrara marble from Pisa Tower is also attributed to the growth of fungal species Sporotrichum [50].

\section{Fungal diagenesis}

It is a complex process of biochemical [46] and biomechanical alterations $[47,51]$ of carbonate substrates induced by fungus resulting in the formation of different secondary minerals. Carbonate stones mainly consisted of limestone or dolomite serves as an unusual niche for the fungal communities. These substrates are highly susceptible to fungi and their interaction promotes extensive microbial diagenesis of these substrates. Extensive 
diagenesis results in the dissolution (or bioweathering) of the carbonate substrate due to exuded organic acids (oxalic, citric and malic acid) and transformation of the original minerals of the substrate with new one as consequences of fungal biomineralization process [76].

\section{Lichens}

Lichens grow as a visible film on the stone surface and due to their macroscopic structure, their presence on stones is visibly evident. Lichens represent the symbionts of fungi (mainly ascomycete) and algae (mainly green algae) or fungi and cyanobacteria (less common) [28]. Lichens are comparatively more resistant to extreme temperature and desiccation which allows them to flourish and grow in wide variety of habitats some of them may be hostile to other forms of lives [102,103]. Lichens are among the pioneer organisms which inhabits the exposed stone surfaces. Their growth may be favored by the presence of organic nitrogen rich excretes of birds (crows and pigeons). They have significant contribution in biogeophysical and biogeochemical deterioration of the monumental stone. The $\mathrm{CO}_{2}$ produced during respiration is transformed into carbonic acid (a potent weathering agent) inside the thallus [28]. With the help of their specialized devices like hyphae (crustose lichens) and rhizoids (foliose and fructicose lichens) lichens gain attachment and penetrates into the pores, cracks and fissures of the stones leading to structural and physical damage [26]. Their metabolic activities are often associated with the release of highly corrosive organic carboxylicx acids (like oxalic acid etc) and chelating compounds by which they form complexes with the mineral cations of the substratum [24,78]. Nitrogen fixation by them is also known to improve the bioweathering potential [30]. Recently documented lichen acids, a group of polyphenolic compounds such as anthraquinones [24] having polar moiety that chelates metallic cations by donating electron pair cause chemical deterioration of the monumental stones through the process of bioweathering. After death, lichens leave behind a pitting corrosion with etch mark due to their metabolic activity and to the incorporation of mineral fragments into the thallus. The contraction-expansion of the lichens as a consequence of desiccation and rehydration results in peeling and detachment of superficial mineral layer [28]. Their presence was also suspected for the formation of oxalate layer on patinas $[24,28]$.

Fungi within lichens are known to secrete several hundred compounds known as lichen substance. Lichen substances include simple aliphatic organic acids, aromatic polyphenol compounds (such as depsides, depsidones, depsones and carotenoids) [27,74] and chelating agents (such as norstictic, psoromic, iso-usnic, and usnic acid) [27]. It was believed that some of these lichen substances have got role in extraction of nutrients from the mineral surface of stone $[27,74]$. The Lichen-stone mineral interaction was demonstrated in few studies where the presences of some lichen substances like usnic acid, zeroin, and leucotylin (in Lecanora muralis), divaricatic and usnic acid (in Ophioparma ventosa), parietina and rhizocarpic acid (in Xanthoria elegans) and thamnolic acid (in Ophioparma ventosa and Pertusaria corallina) were not reported to be linked with any sort of biodeterioration $[52,104]$.

\section{Mosses and liverworts}

Mosses and liverworts are bryophytes which develop and grow on the surface with abundance of humus deposits. Accumulation of atmospheric particles and dead microorganisms (algae) constitutes the major portion of humus. These are photosynthetic organisms with characteristic pigments but lacking vascular tissues. Their presence is most evident with algae in tropical environment and damp surfaces of monuments. The damage caused by them (usually green-grey patches) is mainly associated with aesthetic appearance but other damages are also known. The carbonic acid produced by them as a result of cellular respiration cause damage to stone over an extended period of time. The extraction of mineral cations from the stones by them is well documented [33,60,61,70]. There are literatures that had also showed the ability of mosses (Grimmia pulvinata (Hedw.) Sm.) to uptake calcium and established their role in biodeterioration but their role in biodeterioration of monuments and art works is still considered as negligible [33]. They possess structures called rhizoids which physical intrude the stone surface but any mechanical damages caused by them is not reported yet. Death on mosses causes indirect damage to monuments and stones by enriching and increasing the humus content which supports the growth of successive species higher plant.

\section{Microbial succession and monuments deterioration: relation Do exist}

The colonization of microbial communities on the bare surface of monuments and artworks is mainly determined by the nature and properties of stone surface (surface texture, mineral composition, percentage of different minerals, $\mathrm{pH}$, moisture content and salinity etc.) and surrounding environment conditions (Figure 1). The exposed inorganic mineral surface of the monumental stones and artworks serves as a suitable niche for the growth and development of the pioneer microorganisms which includes photoautotrophs, lithophiles and chemolithotrophs (Figure 1). Microbial colonization on bare stone surface is thought to be initiated by pioneering phototrophic cyanobacteria and algae, probably followed by lichens, and then general heterotrophs, as heterotrophic communities have ability to grow on rocks 
having initial phototrophic biomass [41] (Figure 1). Phototrophic microorganism which mainly includes cyanobacteria, green algae and lichens are reported to harm the stone surface aesthetically by their secreted pigments. However, secreted organic acids, polyphenolic compounds such as anthraquinones [24] cause chemical deterioration through the process of bioweathering. In tropical climate, (high temperature, high relative humidity and high annual rainfall) these organisms may secrete carbohydrates and growth factors which helps in the formation of biofilm (a three-dimensional structure regulating temperature and humidity) and consequently facilitates the growth of diverse microbial communities within it. The lithophiles population is principally consisted of epilithic (dwelling on surface) and endolithic (residing few $\mathrm{mm}$ inside the stone pores) bacteria which promote the breakdown of crystalline structure contributing towards pedogenesis $[8,10]$. Biological and metabolic activities and death of these organisms and photosynthetic biomass often fertilizes the surface with organic matters and growth factors which support the growth of successive microbial communities which is predominated by heterotrophic bacteria and fungi. Some organisms are also benefited by the accumulation of ammonia and phosphates coming the atmosphere. Phototrophic algae, lichens and heterotrophic bacteria are also found to be mutually interacts with each other where organic acids produced by phototrophs serves as carbon source for the heterotrophs and both grow unrestricted over a periods of several months [55]. Some of these microorganisms also show pedogenetic actions, making the stone surface powdery and pave the path for succession of mosses and liverwort. Mosses and liverwort occur on substrate with high humus content and contain deposits of dead algal cells. Progressive accumulation of humus and death of mosses favor the emergence of higher plant species.

\section{Conclusions}

The current research in the field of geomicrobiology has extended our knowledge and understanding of the role of microbes in biodeterioration of historic monuments and artworks. Subsequently, it was felt that the field although maturing needs to unravel the underlying mechanism and cause of destruction to monuments and artworks. Merely, identification and characterization of the biodeteriogens cannot solve the problem of biodeterioration. Additional investigation of various biogeochemical and biogeophysical alterations brought about by action of microorganisms on stone surfaces and the mechanistic studies of alterations is equally worthy to be researched out. Besides this, as certain bacterial and fungal species have inherent capability to act upon the applied protective resins and other covering and use them as source of energy [56], stone surfaces once treated should also looked thereafter routinely so as to check reoccurrence of microbial growth. Moreover, some species of microorganism had acquired resistance to applied biocides [64], which has led intensive research towards formulation of potent biocides.

Evaluation of the factors promoting microbial activity (microbial adherence, growth and survival) on stone surface and understanding the mechanism of deterioration caused to stone surface by them is very essential for designing an appropriate conservation and restoration strategy [70]. Additionally the knowledge of bioreceptivity, which is defined as the totality of materials properties that contribute to the adherence, establishment and colonization of fauna and/or flora on the stone surface of monuments and artworks [72] may be exploited as an important tool for recognizing the biodeterioration process induced by microorganisms and for developing conservation and restoration campaigns. After identification of microorganism and type of deterioration associated with monuments and artworks, the next step is to employ the molecular strategies like Scanning Electron Microscopy (SEM), 16s-RNA Sequencing [9], Denaturing DNA Gel Electrophoresis [9], Temperature Gradient Gel Electrophoresis, Terminal Restriction Fragment Length Polymorphism, X-ray Diffraction (XRD), Laser Induced Fluorescence, Bioinformatics tools, for instance, BLAST, NJ etc. and physical techniques such as Raman Spectroscopy, FT-IR, Mössbauer Spectrometry, Induction Coupled Plasma-Mass Spectrometry, Thermal Analysis, Laser Induced Fluorescence, Fluorescence LIDAR, Thin-layer Petrography, Mercury Intrusion Porosimetry etc. to gain more insight into the cause and mechanism of deterioration processes.

\section{Competing interests}

The authors declare that they have no competing interests.

\section{Authors' contribution}

The idea was conceived by SSC. The manuscript has been written by TCD. Major technological and English corrections have been done by SSC. All authors read and approved the final manuscript.

\section{Acknowledgements}

We would like to thank the Director, Institute of Microbial Technology (CSIR, Govt. of India) for providing the facility for writing this review paper.

\section{Author details}

Present Address of TCD: University of Modena and Reggio Emilia, Reggio Emilia, Italy. Institute of Microbial Technology, Sector 39A, Chandigarh, India.

Received: 15 February 2012 Accepted: 8 October 2012

Published: 25 November 2012

\section{References}

1. Dakal TC, Cameotra SS: Geomicrobiology of cultural monuments and artworks: mechanism of biodeterioration, bioconservation strategies and applied molecular approaches. In Bioremediation: Biotechnology, Engineering, and Environment Management. Edited by Mason AC. New York: Nova Science Publishers; 2011.

2. Ortega-Calvo JJ, Naturales R, Saiz-Jiminez C: Biodeterioration of building materials by cyanobacteria and algae. Int Biod 1991, 28:165-185. 
3. Ortega-Calvo JJ, Hernandez-Marine M, Saiz-Jimenez C: Biodeterioration of building materials by cyanobacteria and algae. Int Biod 1991, 28:165-185.

4. Ortega-Calvo JJ, Arino X, Hernandez-Marine M, Saiz-Jimenez C: Factors affecting the weathering and colonization of monuments by phototrophic microorganisms. Sci Tot Environ 1995, 167:329-341.

5. Nuhoglu Y, Oguz E, Uslu H, Ozbek A, Ipekoglu B, Ocak I, Hasenekoglu I: The accelerating effects of the microorganisms on biodeterioration of stone monuments under air pollution and continental cold climatic conditions in Erzurum, Turkey. Sci Tot Environ 2006, 364:272-283.

6. Grossi CM, Brimblecombe P, Esbert RM, Alonso FJ: Color changes in architectural limestones from pollution and cleaning. Color Res App/ 2006, 32:320-331.

7. Saiz-Jimenez C, Laiz L: Occurrence of halotolerant/halophilic bacterial communities in deteriorated monuments. Int Biod Biodegr 2000, 46:319-326.

8. Ortega-Calvo JJ, Hernandez-Marine M, Saiz-Jimenez C: Isolation and characterization of epilithic chlorophytes and cyanobacteria from two Spanish cathedrals (Salamanca and Toledo). Nova Hedwigia 1993, 57:239-253.

9. Piñar G, Ripka K, Weber J, Sterflinger $K$ : The micro-biota of a sub-surface monument the medieval chapel of St. Virgil (Vienna, Austria). Int Biod Degrad 2009, 63:851-859.

10. Scheerer S, Ortega-Morales O, Gaylarde C: Microbial Deterioration of Stone Monuments-An Updated Overview. Adv Appl Microbiol 2009, 66:97-139.

11. Flores M, Lorenzo J, Gomez-Alarcon G: Algae and bacteria on historic monuments at Alcala de Henares, Spain. Int Biod Biod 1997, 40:241-246.

12. Zammit G, Psaila P, Albertano P: An investigation into biodeterioration caused by microbial communities colonizing artworks in three Maltese Palaeo-Christian Catacombs. In 9th International Conference on NDT of Art Jerusalem Israel; 2008. 25-30 May 2008.

13. Sprocati AR, Alisi C, Tasso F, Vedovato E, Barbabietola N, Cremisini C: A microbial survey of the Etruscan Mercareccia Tomb (Italy): Contribution of microorganisms to deterioration and restoration. In 9th International Conference on NDT of Art. Jerusalem Israel; 2008.

14. Caneva G, Nugari MP, Ricci S, Salvadori O: Pitting of marble Roman monuments and the related microflora. In Proceedings of the 7th International Congress on Deterioration and Conservation of Stone. Edited by Delgado J, Henriques F, Telmo F. Lisbon: Laborato' rio Nacional de Engenharia Civil; 1992.

15. Kramar S, MirTič B: Characterization of black crusts of Robba's fountain statues, Ljubljana (Slovenia). RMZ Mater Geoenviron 2008, 55:490-504.

16. Sarró MI, Garcia AM, Rivalta VM, Moreno DA, Arroyo I: Biodeterioration of the Lions Fountain at the Alhambra Palace, Granada (Spain). Build Environ 2006, 41:1811-1820

17. Cuzman OA, Ventura S, Sili C, Mascalchi C, Turchetti T, D'Acqui LP, Tiano P: Biodiversity of phototrophic biofilms dwelling on monumental fountains. Microb Ecol 2010, 60:81-95.

18. Crispim CA, Gaylarde CC: Cyanobacteria and biodeterioration of cultural heritage: A Review. Microb Ecol 2005, 49:1-9.

19. Gaylarde CC, Morton LHG: Deteriogenic biofilms on buildings and their control: a review. Biofouling 1999, 14:59-74.

20. Hernandez-Marine M, Clavero E, Roldan M: Why there is such luxurious growth in the hypogean environments. Arch Hydrobiol Suppl Algol Stud 2003, 109:229-239.

21. Ramírez M, Hernandez-Marine M, Novelo E, Roldan M: Cyanobacteriacontaining biofilms from a Mayan monument in Palenque, Mexico. Biofouling 2010, 26:399-409.

22. Tomaselli L, Lamenti G, Bosco M, Tiano P: Biodiversity of photosynthetic microorganisms dwelling on stone monuments. Int Biod Biodegr 2000 46:251-258

23. Warscheid T, Braams J: Biodeterioration of stone: a review. Int Biod Biodegr 2000, 46:343-368.

24. Adamo $P$, Violante $P$ : Weathering of rocks and neogenesis of minerals associated with lichen activity. Appl Clay Sci 2000, 16:229-256.

25. Del Barrio SV, Garcia-Vallès M, Pradell T, Vendrell-Saz M: The red-orange patina developed on a monumental dolostone. Engg Geol 2002, 63:31-38.

26. Favero-Longo SE, Castelli D, Salvadori O, Belluso E, Piervittori R: Pedogenetic action of the lichens Lecidea atrobrunnea, Rhizocarpon geographicum gr. and Sporastatia testudinea on serpentinized ultramafic rocks in an alpine environment. Int Biodet Biod 2005, 56:17-27.
27. Huneck S, Yoshimura I: Identification of lichen substance. Berlin: SpringerVerlag; 1996.

28. Oksanen I: Ecological and biotechnological aspects of lichens. App/ Microbiol Biotechnol 2006, 73:723-734.

29. Pavía S, Caro S: Origin of Films on Monumental Stone. Stud Conserv 2006 , 51:177-188.

30. Seneviratne $G$, Indrasena IK: Nitrogen fixation in lichens is important for improved rock weathering. J Biosci 2006, 31:639-643.

31. Zurita YP, Cultrone G, Sanchez-Castilo P, Sebastain E, Boliver FC: Microalgae associated with deteriorated stonework of the fountain of Bibatauın in Granada, Spain. Int Biod Biodegr 2005, 55:55-61.

32. Lamenti $G$, Tiano $P$, Tomaselli L: Biodeterioration of ornamental marble statues in the Boboli Gardens (Florence, Italy). J Appl Phycol 2006, 12:427-433.

33. Altieri A, Ricci S: Calcium uptake in mosses and its role in stone biodeterioration. Int Biod Degra 1997, 40:201-204.

34. Saiz-Jimenez C: Biodeterioration of stones in historic building and monuments. In Biodeterioration Research 4: Mycotoxins, Wood Decay, Plant Stress, Biocorrosion, and General Biodeterioration. Edited by Llewellyn GC, Dashek WW, O'Rear CE. The Netherlants: Plenum; 1994.

35. Böke H, Gokturk EH, Caner-Saltik EN, Demirci S: Effect of airborne particle on $\mathrm{SO}_{2}$-calcite reaction. App/ Surf Sci 1999, 140:70-82.

36. Brimblecombe $P$, Grossi CM: The rate of darkening of material surfaces. In Air Pollution and Cultural Heritage. Edited by Saiz-Jimenez C. Lisse: A.A. Balkema; 2004

37. Cultrone G, Arizzi A, Sebastain E, Rodriguez-Novarro C: Sulfation of calcitic and dolomitic lime mortars in the presence of diesel particulate matter. Environ Geol 2008, 56:741-752.

38. Mansch R, Bock E: Biodeterioration of natural stone with special reference to nitrifying bacteria. Biodegradation 1998, 9:47-64.

39. MCAlister JJ, Smith BJ, Torok A: Element partitioning and potential mobility within surface dusts on buildings in a polluted urban environment, Budapest. Atmos Environ 2006, 40:6780-8790.

40. Rodriguez-Navarro C, Sebastian E: Role of particulate matter form vehicle exhaust on porous building stones (limestone) sulfation. Sci Tot Environ 1996, 187:79-91.

41. Saarela M, Alakomi HL, Suihko ML, Maunuksela L, Mattila-Sandholm T: Heterotrophic microorganisms in air and biofilm samples from Roman catacombs with a special emphasis on actinobacteria and fungi. Int Biod Biodeg 2004, 1:27-37.

42. Albertano P, Urzì C: Structural interactions among epilithic cyanobacteria and heterotrophic microorganisms in roman hypogea. Microb Ecol 1999, 38:244-252

43. Kumar R, Kumar AV: Biodeterioration of Stones in Tropical Environments.: The Getty Conservation Institute; 1999

44. Adeyemi $A O$, Gadd GM: Fungal degradation of calcium-, lead- and silicon-bearing minerals. Biometals 2005, 18:269-281.

45. Banfield JF, Barker WW, Welch SA, Taunton A: Biological impact on dissolution: application of the lichen model to understanding mineral weathering in the rhizosphere. Proc Natl Acad Sci USA 1999, 96:3404-3411.

46. Burford EP, Fomina M, Gadd GM: Fungal involvement in bioweathering and biotransformation of rocks and minerals. Miner Mag 2003, 67:1127-1155

47. Burford EP, Kierans M, Gadd GM: Geomycology: fungal growth in mineral substrata. Mycologist 2003, 17:98-107.

48. Crispim CA, Gaylarde PM, Gaylarde CC: Algal and cyanobacterial biofilms on calcareous historic buildings. Curr Microbiol 2003, 46:79-82.

49. Harley $A D$, Gilkes RJ: Factors influencing the release of plant nutrient elements from silicate rock powders: a geochemical overview. Nutr Cycl Agroecosyst 2000, 56:11-36.

50. Monte M: Oxalate film formation on marble specimens caused by fungus. J Cul Herit 2003, 4:255-258.

51. Sterflinger K: Fungi as geologic agents. Geomicrobiol J 2000, 17:97-124.

52. Cicek A, Aslan A, Yazici K, Koparal AS: Effects of environmental conditions on historical buildings: lichens and NOx gases. Environ Monit Assess 2009 154:187-195.

53. Seaward MRD, Edwards HGM: Lichen-substratum interface studies, with particular reference to Raman microscopic analysis: 1. Deterioration of works of art by Dirinia massiliensis forma sorediata. Cryptogam Bot 1995, 5:282-287. 
54. Di Bonaventura MP, Del Gallo M, Cacchio P, Ercole C, Lepidi A: Microbial formation of oxalate films on monument surfaces: bioprotection or biodeterioration? Geomicrobiol J 1999, 16:55-64

55. De la Torre MA, Gómez-Alarcón G, Melgarejo P, Saiz-Jimenez C: Fungi in weathered sandstone from Salamanca cathedral, Spain. Sci Tot Environ 1991, 107:159-168

56. Cappitelli C, Prinicipi P, Pedrazzani R, Toniolo L, Sorlini C: Bacterial and fungal deterioration of the Milan Cathedral marble treated with protective synthetic resins. Sci Tot Environ 2007, 385:172-181.

57. Dupont J, Jacquet C, Dennetière B, Lacoste S: Invasion of the French Paleolithic painted cave of Lascaux by members of the Fusarium solani species complex. Mycologia 2007, 99:526-533.

58. Berner M, Wanner G, Lubitz W: A comparative study of the fungal flora present in medieval wall paintings in the chapel of the castle Herberstein and in the parish church of St Georgen in Styria, Austria. Int Biod Degrad 1997, 40:53-61.

59. Ciferri O: Microbial degradation of paintings. Appl Environ Microbiol 1999, 65:879-885

60. Gómez-Alarcón G, Munoz ML, Flores M: Excretion of organic acids by fungal strains isolated from decayed sandstone. Int Biod Degrad 1995, 34:169-180.

61. Gómez-Alarcón G, Munoz ML, Arino X, Ortega-Calvo JJ: Microbial communities in weathered sandstones: the case of Carrascosa del Campo church, Spain. Sci Tot Environ 1995, 167:249-254.

62. Miller AZ, Macedo MF: Mapping and characterization of a green biofilm inside of Vilar de Frades Church (Portugal). In Heritage, Weathering and Conservation. Edited by Fort R, De Buergo MA, Gomez-Heras M, VazquezCalvo C:: Taylor \& Francis; 2006

63. Laiz L, Miller AZ, Akatova E, Sanchez-Moral S, Gonzalez JM, Dionisio A, Macedo MF, Saiz-Jimenez C: Isolation of five Rubrobacter strains from biodeteriorated monuments. Naturwissenschaften 2009, 96:71-79.

64. Bolívar FC, Sánchez Castillo PM: Biomineralization processes in the fountain of Alhambra, Granada, Spain. Int Biodet Biodegr 1997, 40:205-215

65. Miller AZ, Liaz L, Dionisio A, Macedo MF, Saiz-Jimenez C: Growth of phototrophic biofilms from limestone monuments under laboratory conditions. Int Biod Biodegr 2009, 63:860-867.

66. Monte M: Biogenesis of oxalate patinas on marble specimens in fungal culture. Aerobiologia 2003, 19:271-275.

67. Bellinzoni AM, Caneva G, Ricci S: Ecological trends in travertine colonization by pioneer algae and plant communities. Int Biod Biodegr 2003, 51:203-210.

68. Isocrono D, Matteuci E, Ferrarese A, Pensi E, Piervittori R: Lichen colonization in the city of Turin ( $\mathrm{N}$ Italy) based on current and historical data. Environ Poll 2007, 145:258-265.

69. Webster A, May E: Bioremediation of weathered-building stone surfaces. Trends Biotech 2006, 24:255-260.

70. Gaylarde C, Silva MR, Warscheid T: Microbial impact on building materials: an overview. Mater Struct 2003, 36:342-352.

71. Prieto B, Silva B: Estimation of potential bioreceptivity of granitic rocks from their intrinsic properties. Int Biod Biodeg 2005, 56:206-215.

72. Guillitte O: Bioreceptivity: a new concept for building ecology studies. Sci Tot Environ 1995, 167:P215-P220.

73. Di Pippo F, Bohn A, Congestri R, De Philippis R, Albertano P: Capsular polysaccharides of cultured phototrophic biofilms. Biofouling 2009, 25:495-504

74. Purvis W: Lichen. Washington, DC.: Smithsonian Inst. Press; 2000

75. Neaman A, Chorover J, Brantley SL: Implication of the evolution of organic acid moieties for basalt weathering over ecological time. Am J Sci 2005, 305:147-185.

76. Gadd GM, Sayer JA: Fungal transformations of metals and metalloids. In Environmental Microbe-Metal Interactions. Edited by Lovley DR. Washington D.C.: American Society of Microbiology; 2000.

77. Gadd GM: Geomycology: biogeochemical transformations of rocks, minerals, metals and radionuclides by fungi, bioweathering and bioremediation. Mycol Res 2007, III:3-49.

78. Kiurski JS, Ranoqajec JG, Ujhelji AL, Radeka MM, Bokorov MT: Evaluation of the effect of lichens on ceramic roofing tile by scanning electron microscopy and energy-dispersive spectroscopy analyses. Scanning 2005, 27:113-119.

79. Toniolo L, Zerbi CM, Bugini R: Black layers on historical architecture. Environ Sci Pollut Res 2009, 16:218-226.
80. Edwards HGM, Seaward MRD, Attwood SJ: FT-Raman spectroscopy of lichens on dolomitic rocks: an assessment of metal oxalate formation. Analyst 2003, 128:1218-1221.

81. Albertano P, Moscone D, Palleschi G, Hermosin B, Saiz-Jimenez C, SanchezMoral S, Hernandez-Marine M, Urzi C, Groth I, Schroeckh V, Saarela M, Mattila-Sandholm T, Gallon JR, Graziottin F, Bisconti F, Giuliani R: Cyanobacteria attack rocks (CATS): control and preventive strategies to avoid damage caused by cyanobacteria and associated microorganisms in Roman hypogean monuments. In Molecular Biology and Cultural Heritage. Edited by Saiz-Jimenez C. Balkema, Lisse; 2003.

82. Gorbushina AA, Broughton WJ: Microbiology of the atmosphere-rock interface: How biological interactions and physical stresses modulate a sophisticated microbial ecosystem. Annu Rev Microbiol 2009, 63:431-450.

83. Novelo E, Ramírez M: Algae and cyanobacterial diversity and distribution patterns on Mayan buildings in Palenque, Chiapas. Cyanobacterial diversity and ecology on historic monuments in Latin America. Rev Latinoam Microbiol 2006, 48:188-195.

84. Gorbushina AA, Krumbein WE: Subaerial microbial mats and their effects on soil and rock. In Microbial Sediments. Edited by Riding RE, Awramik SM. Berlin: Springer-Verlag; 2000.

85. Wynn-Williams DD: Cyanobacteria in deserts - life at the limit? In The Ecology of Cyanobacteria - Their Diversity in Time and Space. Edited by Whitton BA, Potts M. Dordrecht, The Netherlands: Kluwer Academic Publishers; 2000

86. Fleming ED, Castenholz RW: Effects of periodic desiccation on the synthesis of the UV-screening compound, scytonemin, in cyanobacteria. Environ Microbiol 2007, 9:1448-1455.

87. Seneviratne $G$, Jayasinghearachchi HS: A rhizobial biofilm with nitrogenase activity alters nutrient availability in a soil. Soil Biol Biochem 2005, 37:1975-1978.

88. Albertano $P$, Kovacik L: Light and temperature responses of terrestrial sciaphilos strains of Leptolyngbya sp. in cross-gradient cultures. Arch Hydrobiol Suppl Algol Stud 1996, 83:17-28.

89. Schiavon N: Biodeterioration of calcareous and granitic building stones in urban environments. In Natural Stone, Weathering Phenomena, Conservation Strategies and Case Studies. Edited by Siegemund S, Weiss T, Vollbrecht A. London: Geological Society; 2002.

90. Carter NEA, Viles HA: Lichen hotspots: raised rock temperatures beneath Verrucaria nigrescens on limestone. Geomorpho 2004, 62:1-16.

91. Fitzner B, Heinrichs K, Bouchardiere DL: Limestone weathering of historical monuments in Cairo, Egypt. In Natural Stone, Weathering Phenomena, Conservation Strategies and Case Studies. Edited by Siegemund S, Weiss T, Vollbrecht A. London: Geological Society; 2002.

92. Török A: Leithalkalk-type limestones in Hungary: an overview of lithologies and weathering features. In Architectural and Sculptural Stone in Cultural Landscape. Edited by Prikryl R, Siegl P. Prague: Karolinum Press; 2004.

93. Hoffmann L: Caves and other low-light environments: aerophytic photoautotrophic microorganisms. In Encyclopedia of Environmental Microbiology. Edited by Bitton G. New York: John Wiley; 2002.

94. Roldan M, Clavero E, Castel S, Hernandez-Marine M: Biofilms fluorescence and image analysis in hypogean monuments research. Arch Hydrobiol Algologic Stud 2004, 111:127-143.

95. Albertano $P, B$ Buno $L$ : The importance of light in the conservation of hypogean monuments. In Molecular Biology and Cultural Heritage. Edited by Saiz-Jimenez C. Balkema, Lisse; 2003.

96. Groth I, Saiz-Jimenez C: Actinomycetes in hypogean environments. Geomicrobiol J 1999, 16:1-8

97. Urzì C, Brusetti L, Salamone P, Sorlini C, Stachebrandt E, Doffonchio D: Biodiversity of Geodermatophilaceae isolated from altered stones and monuments in the Mediterranean basin. Environ Microbiol 2001, 3:471-479.

98. Urzì C, Realini M: Colour changes of Noto's calcareous sandstone as related to its colonisation by microorganisms. Int Biod Biodegr 1998, 42:45-54.

99. Allemand L, Bahn PG: Best way to protect rock art is to leave it alone. Nature 2005, 433:800.

100. Gadd GM: Mycotransformation of organic and inorganic substrates. Mycologist 2004, 18:60-70.

101. Lee MR, Parsons I: Biomechanical and biochemical weathering of lichenencrusted granite: textural controls on organic-mineral interactions and deposition of silica-rich layers. Chem Geol 1999, 161:385-397.

102. Kranner I, Cram WJ, Zorn M, Wornik S, Yoshimura I, Stabeentheiner E, Pfeifhofer HW: Antioxidants and photoprotection in a lichen as compared 
with its isolated symbiotic partners. Proc Natl Acad Sci USA 2005, 102:3141-3146.

103. Vrablikova H, McEvoy M, Solhaug KA, Bartak M, Gauslaa Y: Annual variation in photoacclimation and photoprotection of the photobiont in the foliose lichen Xanthoria parietina. J Photochem Photobiol B 2006, 83:151-162.

104. Bjelland T, Thorseth IH: Comparative studies of the lichen-rock interface of four lichens in Vingen, western Norway. Chem Geol 2002, 192:81-98.

doi:10.1186/2190-4715-24-36

Cite this article as: Dakal and Cameotra: Microbially induced

deterioration of architectural heritages: routes and mechanisms

involved. Environmental Sciences Europe 2012 24:36.

\section{Submit your manuscript to a SpringerOpen ${ }^{\circ}$} journal and benefit from:

- Convenient online submission

- Rigorous peer review

- Immediate publication on acceptance

- Open access: articles freely available online

- High visibility within the field

- Retaining the copyright to your article 